\section{A CRITICAL OVERVIEW OF THE BELGRADE CLIMATE CHANGE ADAPTATION ACTION PLAN}

\section{КРИТИЧКИ ПРИКАЗ АКЦИОНОГ ПЛАНА АДАПТАЦИЈЕ БЕОГРАДА НА КЛИМАТСКЕ ПРОMЕНЕ}

Рад примљен: новембар 2016., рад прихваћен: октобар 2017.

Мирјана Деветаковић*, Милан Радојевић**

\section{ABSTRACT}

In the European context, the region of the Western Balkans is seen as one significantly affected by the actual climate changes. Using experiences from numerous European cities that are already adapting to their changing climates,the capital cities of the Western Balkans countries are starting to develop strategies of adaptation to actual and expected climate conditions.In this article we give an overview of the document titled Climate Change Adaptation Action Plan with Vulnerability Assessment issued by the City of Belgrade, Secretariat for Environmental Protection. After giving a brief introduction on the document creation within the project Climate Change Adaptation in the Western Balkansand the methodology applied, a structure of the document has been presented highlighting proposed adaptation actions. The paper continues with a critique of the document, main point of which is a lack of indication of financial sources for the proposed actions, as well as interlinking with national adaptation strategies and disaster risk reduction for the parts of the city particularly affected with the floods in 2014.

Keywords: climate change, adaptation, actions, Belgrade, Western Balkans

\section{АПСТРАКТ}

У европском контексту, подручје Западног Балкана сматра се једним од највише погођених актуелним климатским променама. Користећи искуства бројних европских градова који су усвојили мере адаптације на измењене климатске услове, главни градови земаља Западног Балкана започињу креирање стратегија прилагођавања на постојеће и очекиване климатске промене. У овом раду дат је критички осврт на документ под насловом Акциони план адаптације на климатске промене са проценом рањивости који је публиковао Секретаријат за заштиту животне средине Града Београда. Након кратког осврта на настанак овог документа у оквиру пројекта Адаптација

* dr Mirjana Devetaković, University of Belgrade, Faculty of Architecture, Bulevar kralja Aleksandra 73/2, 11000 Beograd, tel. +381113218748, mirjana. devetakovic@gmail.com

* dr Milan Radojević, University of Belgrade, Faculty of Architecture, Bulevar kralja Aleksandra 73/2, 11000 Beograd, tel. +381113210770,milan@arh.bg.ac.rs на климатске промене у земљама Западног Балкана, као и на примењену методологију, приказана је структура целокупног документа са акцентом на предложене мере адаптације. Рад се наставља критиком приказаног документа, чија је кључна тачка одсуство индикације 0 финансијским аспектима подршке предложеним мерама адаптације, као и повезивање/формирање националне стратегије адаптације на климатске промене и докумената о редукцији ризика од природних катастрофа за делове града који су нарочито били угрожени у поплавама 2014.

Кључне речи: климатске промене, адаптација, акције, Београд, Западни Балкан

\section{INTRODUCTION}

The ongoing climate changes are a global phenomenon, influencing various regions worldwide, including majority of European countries (Dimitrijević, 2013 (a): 20). The climate changes are spatially distributed and affect economies, ecologic and energetic systems, social and urban life (Pucar, 2016: 10). In coping with the climate changes it is possible to distinguish mitigation and adaptation measures. While the mitigation measures are directed to decreasing negative impacts of mankind and upgrading the climate neutrality culture (Devetaković, Radojević, 2014), the adaptation measures help to adapt to inevitable climate circumstances (Dimitrijević, 2013 (b): 23). The region of Western Balkans is foreseen as one, particularly sensitive to the changing climate'.

\section{The Climate Change Adaptation Action Plan with Vulnerability}

1 "Forecasts indicate that the riparian states of Albania, Kosovo, Macedonia and Montenegro, as well as Serbia, will be particularly vulnerable to the negative impacts of climate change. In the countries concerned, it is generally expected that there will be a rise in average annual temperatures, for example of up to 5.6 degrees Celsius in Albania, and decreased average annual precipitation, for example a reduction of 5 per cent by 2050 in Macedonia. On the one hand this will lead to milder and wetter winters in the region. On the other, extreme weather events are likely to become more frequent, which will increase the risk of flooding, soil erosion and water pollution. Warmer and dry springs will lead to longer dry periods with temperatures exceeding 35 degrees Celsius, especially during the summer months. Considering that the temperatures in urban areas will rise by several degrees, cities such as Tirana and Podgorica could face heat waves of over 45 degrees." (Climate Change Adaptation in the Western Balkans, 2017) 
Assessment is a document adopted by the Assembly of the City of Belgradein October 2015, and publicly promoted in November 2015. It is available as a booklet publication in two languages, Serbian and English, as well as an online publication at: http://klimatskepromenebeograd.rs/ akcioni-plan-adaptacije-na-klimatske-promene-sa-procenomranjivosti/.

The document has been developed under the regional project Climate Change Adaptation in the Western Balkans (2012-2015), funded by GIZ (German International Cooperation Agency), with participation of representatives from Serbia, Macedonia, Albania, Montenegro and Kosovo. The Belgrade Adaptation Plan is last of three similar documents that have been created forcapital cities of Serbia, Albania ${ }^{2}$ and Montenegro ${ }^{3}$.

The document is result of activity of a multisector Working Group, established in September 2014, involving 31 members, mainly representatives of the Belgrade City secretariats related to climate change, led by a managerial group including the City manager, secretary and deputy secretary of the Secretariat for Environmental Protection, representatives of $\mathrm{GIZ}$ and German consultancy agency Infrastruktur\& Umwelt. The Secretariat for Environmental Protection was the main organizer and implementer of the Plan'.

\section{STRUCTURE OF THE ADAPTATION ACTION PLAN}

The document is structured in four parts $5^{5}$ :

- Preface and introduction,

- Vulnerability assessment,

- The assessment of future risks and opportunities, and

- The action plan

In the Preface section of the Adaptation Action Plan, climate change has been identified as one of the biggestcontemporary challenges. The climate change is causing frequent and severe weather events in various part of the world. South-East Europe is a region in which such weather events could be expected to happen more frequently than it was the case in the past decades. It is therefore necessary for the cities like Belgrade to be well prepared and adapted to such situation. The activities on the national strategy and action plan started in September 2015 and are expected to be promoted in 2017.

As capital of Serbia, Belgrade territory is spread on 323 hectares of land, divided in 17 municipalities, where only the core represents an urban structure, while the rest has rural characteristics. The Adaptation Action Plan considered entire administrative territory of Belgrade.

2 Adapting our city to a changeing climate; Vulnerability assesment and adaptation action plan for Tirana, 2015

3 Podgorica Climate Change Adaptation, Vulnerability Assessment and Adaptation Action Plan, 2015

4 Climate Change Adaptation Action Plan with Vulnerability Assesment, 2015, pp.

5 lbid, pp. 10

\section{Legislative framework, definitions and methodology}

In the introduction part, a strategic and legislative framework for the adaptation action plan is given, considering the document as one of many measures of the city adaptation system. The document is connected with the following strategies:

- National Sustainable Development Strategy

- National Environmental Programme

- The Energy Sector Development Strategy until 2015

- The Forestry Development Strategy of the Republic of Serbia

- Strategy of Scientific and Technological Development of Serbia (2010-2015)

- Regional Spatial Plan of the Administrative Territory of the city of Belgrade

- Development Strategy of the City of Belgrade

The national climate change legislative considered in the Adaptation Plan is the following:

- Law on Ratification of the United Nations Framework Convention on Climate Change

- Law on Ratification of the Kyoto Protocol

- Law on Environment

- Law on Strategic Environmental Impact Assessment

- Law on Environmental Impact Assessment

- Law on Integrated Prevention and Control of the Pollution

Prior to explaining the methodological approach the key terms have been defined as following:

"Adaptation denotes adjustments in natural or human system in response to actual or expected climatic changes or their impacts, in order to define actions to:

- understand the risks and opportunities we face from extreme weather today and further changes to our climate in the future

- identify, assess and prioritize the options to manage the risks and opportunities, and

- develop, deliver and monitor actions to manage these risks and realize these opportunities.

The term "vulnerability" refers to the degree to which the system is susceptible to, and unable to cope with, adverse climate or weather induced impacts." 7

The creation of the Adaptation Action Plan is based on the existing methodology developed within the EU project Future Cities (Future Cities Adaptation Compass, 2013). The methodological approach includes two parts: vulnerability assessment and creation of an adaptation action plan. The vulnerability assessment consists of three components: checking vulnerability, understanding climate change impacts and assessing risks and opportunities. The adaptation action plan includes exploring adaptation options and determining the need for action and selected measures (Fig. 1, Ibid. pp. 11). The process is circular, so that information gathered from the Adaptation Action Plan implementation, become input for Vulnerability Re-assessment.

\footnotetext{
6 A broader list and comments on the climate change legislation in Pucar, 2013.

7 Climate Change Adaptation Action Plan with Vulnerability Assesment, 0p. Cit. pp. 10
} 


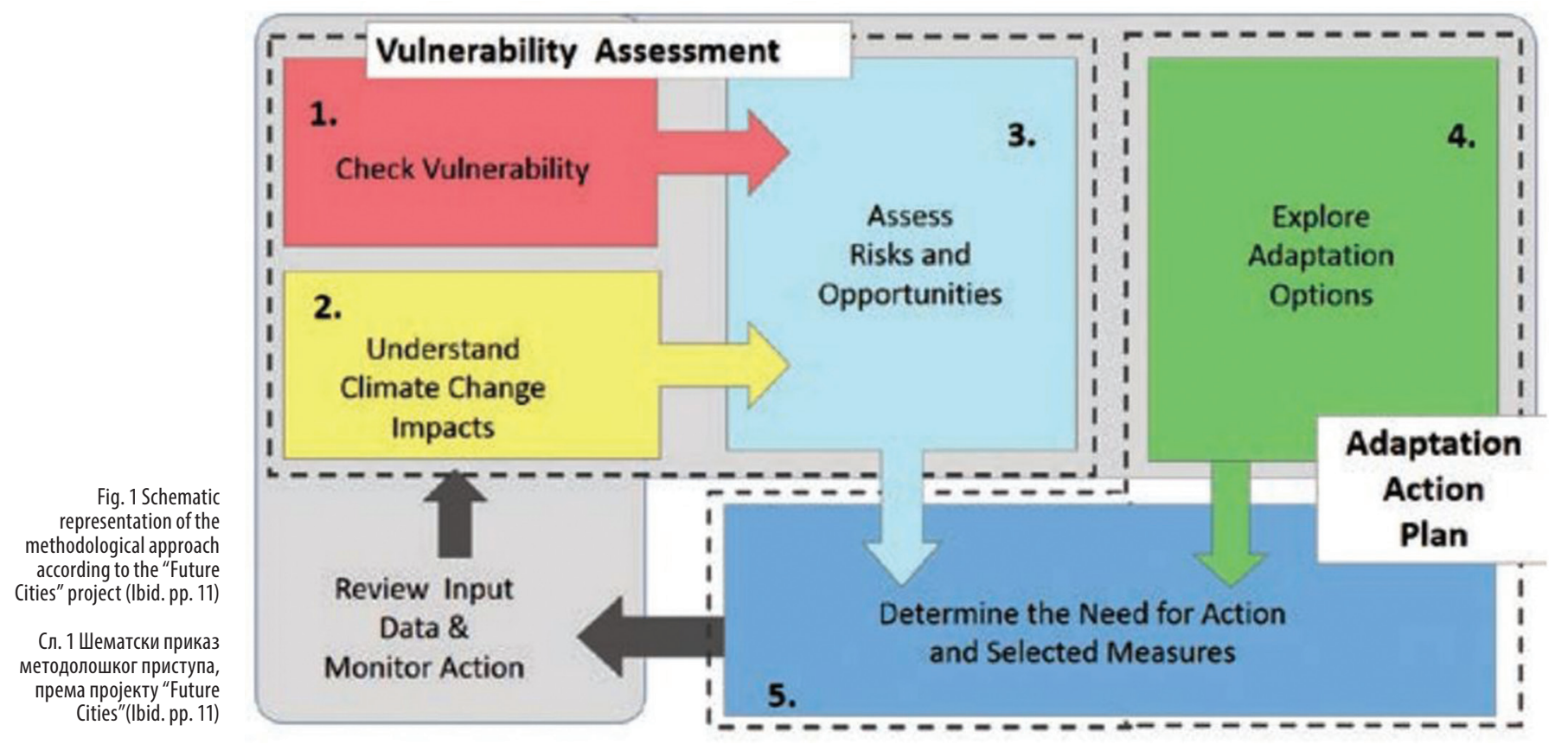

\section{Vulnerability Assessment}

In the section "Assessment of the current vulnerability in Belgrade",the extreme weather events in the past are listed divided in the following groups:

- Heat waves

- Extreme cold

- Droughts

- Heavy precipitations and floods

- Storms

The heat waves have been recorded in 2013, 2012, 2007, 2006, 2003, 2000 and 1998. They were present equally on all the territory of Belgrade, but affected the most vulnerable groups, elderly and children, and people with particular illnesses. It is highly predictable that such events will repeat as a number of consequent days with day temperature above $39^{\circ} \mathrm{Cand} \mathrm{minimal}$ night temperature above $20^{\circ} \mathrm{C}$. The Action plan does not identify particular heat islands in the city but recommends the green infrastructure that has to be spread, especially in the central and high density populated areas. The extreme cold periods have been recorded in 2012, 2009, 2007 and 1998, with 12-20 ice days in winter. They caused transport problems, increased electricity demand and affected most vulnerable groups. Among the several draughts in Belgrade in recent decade, two were highlighted, in summer 2012 and August 2000. They caused restricted availability of drinking water and reduced agricultural production, drying of streams and urban wetland, drying of grasslands, etc. Heavy precipitation and floods are recorded in 2014 and 2006, where in 2014 with a catastrophic dimension (Ibid. pp. 13-16).

The vulnerability of the following receptors has been examined (lbid. 17-22):
a) Population
- Public health/vulnerable groups
b) Infrastructure
- Transport

- Electricity and heating services

- Water supply and sanitation services

- Social infrastructure

c) Built environment

- Building stock and materials (example Figure 2)

d) Economy

- Tourism

- Industry

- Retail

e) Natural resources

- Green spaces

- Water resources and quality

- Agriculture

- Forestry

- Bio-diversity / eco-systems

For each of the receptors general weather sensitivity has been examined as potential effect under an extreme event: heat wave, extreme cold, drought, heavy precipitation/flood, and storm. Detailed tabulated information for the past extreme events is given in the Annex 2 and the assessment of current vulnerability in the Annex 3. Apart from potential effects, it is determined who/what is affected and how strong sensitivity/ exposure, capacity to adapt and consequent vulnerability are. There's a logic connection between the sensitivity/exposure and capacity to adapt, influencing general vulnerability in the following way (Table1):

\begin{tabular}{lll}
\hline sensitivity/exposure & capacity to adapt & vulnerability \\
\hline high & low & high \\
\hline high & medium & high \\
\hline high & high & medium \\
\hline medium & low & high/medium \\
\hline medium & medium & medium \\
\hline medium & high & medium/low \\
\hline low & low & low \\
\hline low & medium & low \\
\hline low & high & low \\
\hline
\end{tabular}

Tab. 1 Determination of the class of vulnerability of receptors Таб. 10дређивање нивоа рањивости рецептора климатских утицаја 


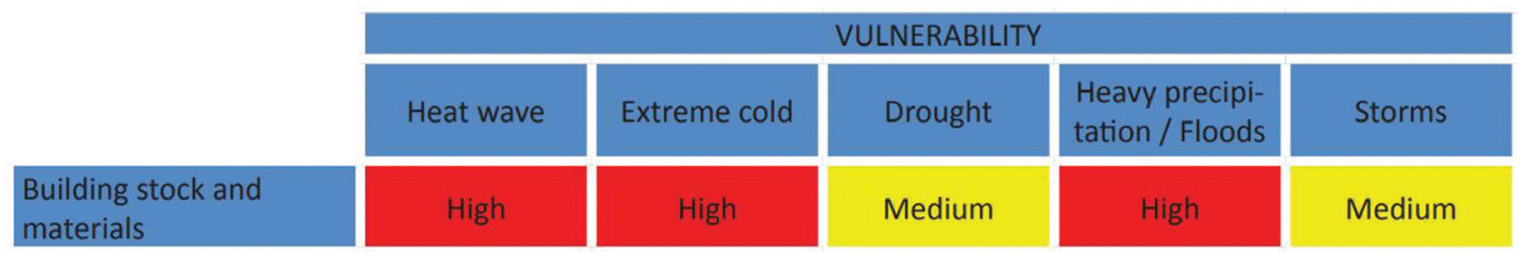

An example of the vulnerability assessment for the built The current vulnerability to extreme weather events has been environment is shown at the following illustration (Fig. 2). mapped for entire administrative territory of Belgrade (Fig. 3).

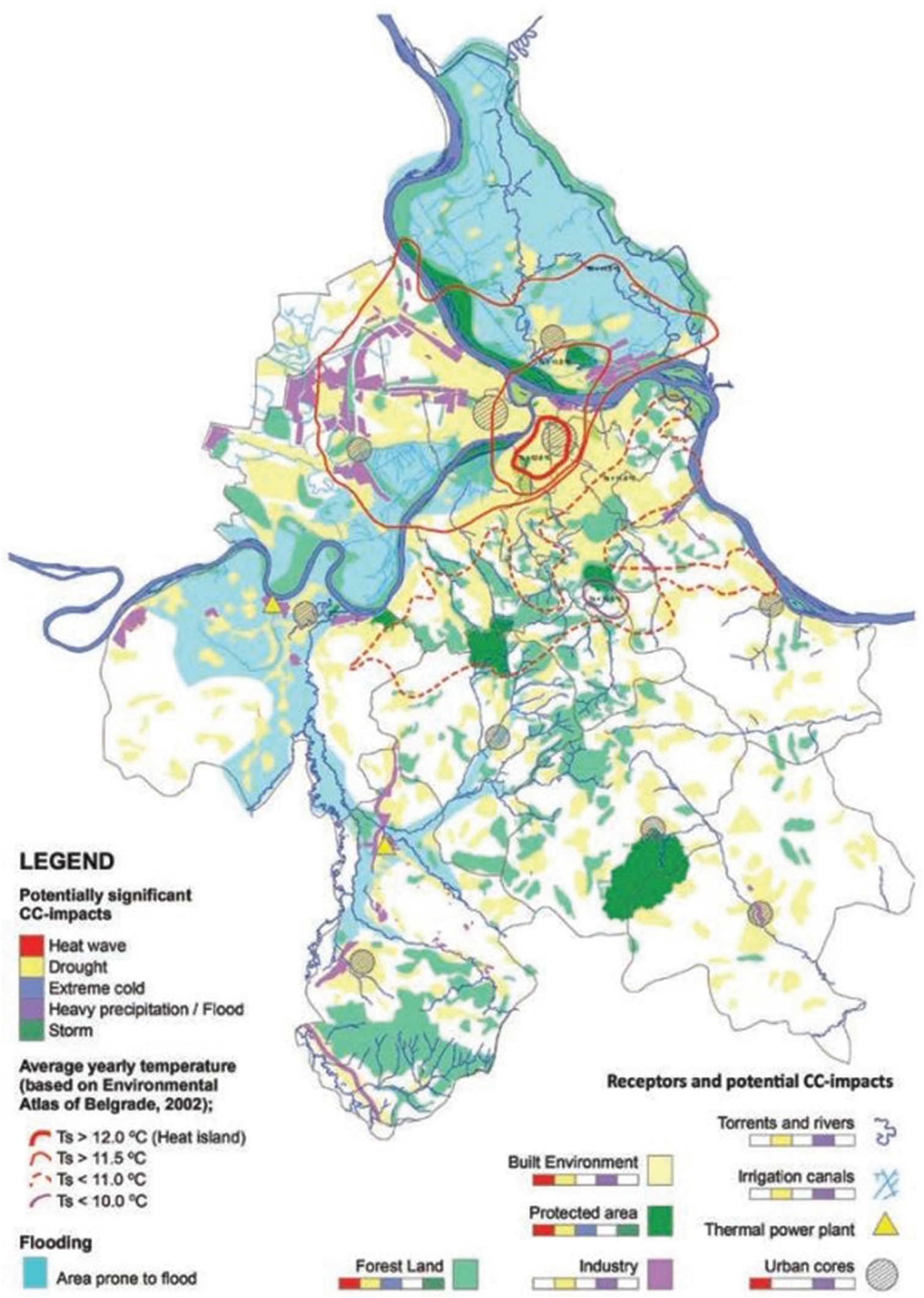

Fig. 2 Assessment of vulnerability of the building stock and materials (Ibid. pp.17)

Сл. 20 дређивање рањивости изграђених објеката и материјала (Ibid. pp.17)

Fig. 3 The administrative territory of Belgrade, potential climate change impacts (Ibid. pp.23)

Сл. 3 Административна територија града Београда, потенцијални утицаји климатских промена (lbid. pp.23) 


\section{Climate Change Trends}

The Climate Change Trends section gives an analysis (19492009) undertaken for the "Initial Communication of Serbia under the United Nations Framework Convention on Climate Change". According to these data the temperature in Belgrade is characterised with the highest increase in Serbia, especially in spring and summer. There's a slight rise in mean annual precipitation, but the number of heavy precipitation daysis on rise.

According to prediction models (medium scenario A1b) compared to the period 1971-2000, the mean annual temperature will rise by $2^{\circ}$ degrees in the period 2021-2050, and $5.6^{\circ}$ from 2071-2100. Number of hot days per year will also increase by 12 from 2021-2050 and by 60 from 2071-2100.

\section{Adaptation actions}

The proposed adaptation actionsplan consists of 23 actions divided in following five parts (lbid. pp.36-41):

a) Urban green systems

- Green infrastructure (example Figure 4)

- Green open spaces

- Green alleys

- Green roofs

- Green walls

b) Water systems

- Flood protection

- Water retention

- Water saving and reuse

- Water drainage

- Extension of water supply services

- Rain water storage c) Urban planning

- Urban planning to avoid flood risk

- Belgrade climate Atlas

- Urban setting

- Urban texture

d) Building design

- Heat adapted design

- Flood adapted design

e) Non-structural measures

- Awareness raising and behaviour change

- Institutional and organizational measures

- Warning system

- Land use and urban planning

- Mapping

For each of the actions a comment or explanation is given, as well as relevant locations and list of implementing agencies of the City of Belgrade. Finally, for each of the actions a priority ranging from low to very high is given, and a time frame ranging from short to long term, where a short term is up to two years, medium term is 2 to 5 years, and long term is a period over ten years.

An example of the climate change adaptation action for the green infrastructure development is given in the Fig. 4:

The "Urban green structures" is the first group of actions ranging from very high to medium priority. A very highly prioritized action is titled "Green infrastructure", assigned as a mid-term, city-wide, to several Belgrade secretariats (Figure 4). It refers to the network of various green spaces that contribute to environmental, economic, cultural, etc. benefits of the life in the city. The "Green open spaces" is a high priority, midterm action towards maintenance existing and creating new green spaces (parks, squares, green spaces within public facilities,
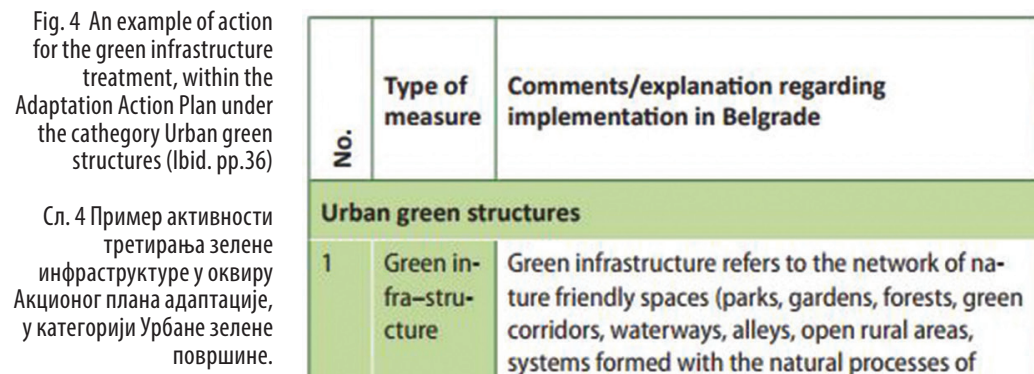

Urban green structures

1 Green in- Green infrastructure refers to the network of nafra-stru- ture friendly spaces (parks, gardens, forests, green cture corridors, waterways, alleys, open rural areas, systems formed with the natural processes of infiltration of rain water, waste water treatment, etc.) that protects and facilitates the maintenance of ecosystem services, or provides environmental, economic, cultural and other benefits to the quality of life of people, plants and animals, as well as their development in natural conditions.

The measure includes:

- assessment of existing green infrastructure features/elements and its functionality in order to identify how it needs to be improved and where there is a need to enhance connectivity;

- improvement of the health of or converting an area/ecosystem back to its natural state;

- creation of connectivity features, new green (urban) areas, sustainable use areas, habitats (forest area, etc.);

\begin{tabular}{l|l|l|}
\hline Relevant locations & $\begin{array}{l}\text { Implementing } \\
\text { agencies }\end{array}$ \\
$\begin{array}{l}\text { City-wide, in accordance with } \\
\text { the concept of green areas } \\
\text { developed in the framework of } \\
\text { the Green Regulation of Belgra- } \\
\text { de and the Plan of General Re- } \\
\text { gulation of the System of Green }\end{array}$ & $\begin{array}{l}\text { - City of Belgrade } \\
\text {-Secretariat for hou- } \\
\text { sing and communal } \\
\text { utilities; } \\
\text {-Secretariat for the } \\
\text { Environment; } \\
\text {-Secretariat for Urban } \\
\text { Planning and Con- } \\
\text { struction; } \\
\text { Public Utility Belgra- } \\
\text { de Greenery; } \\
\text {-Institute for urban } \\
\text { planning of Bel- } \\
\text { grade; } \\
\text {-Serbian Forest Com- } \\
\text { pany; } \\
\text { Other institutions; }\end{array}$ \\
\hline
\end{tabular}


schools and kindergartens, yards of individual residential buildings, etc.) citywide.The high priority, medium term action titled "Green alleys" highlights the maintenance of existing and planting new trees along streets citywide. The medium priority, short term/continuous actions "Green roofs" and "Green walls" is assigned for implementation to Belgrade Greenery, but also to building owners with support of Belgrade Secretariat for Communal Affairs. The green roofs are planned for buildings with flat roofs in central City zone as well as for new public buildings and commercial zones. The action of applying green walls is presumed for new business and commercial centres and the commercial zones along highways ${ }^{8}$.

In the group of actions titled "Water systems", the "Flood protection" action is one with a very high, medium term priority. It presumes reconstruction of existing and construction of new flood protection structures (river dikes, quays, small reservoirs and retentions, along the Sava and Danube banks. As the action of the highest priority, it is under the jurisdiction of both Serbian Water Company and Belgrade Water Company. As storm water control facilities, a system of "Water retention" has been anticipated as a high priority, medium term action, also in domain of Belgrade Water Company. A range of "Water savings" measures (distribution optimization, harvesting and reuse, water saving in households, consumption monitoring in industry...) has been highly prioritized and put in domain of the City of Belgrade Secretariat for Housing and Communal Utilities and the Belgrade Water-works and Sewerage Company. A "Water drainage" system has been anticipated for many Belgrade open channels and streams, and is high priority, medium term action to be implemented by the Belgrade Water Company. An "Extension of water supply services" through increase capacity for drinking water production and building/ repair the system of fountains has been a medium priority, citywide, short term action for Belgrade Water-works and Sewerage Company. Finally the "Rain water storage" has been listed as a low priority, short term action of Belgrade Waterworks and Sewerage Company, envisaging collection and storage of rain water for future use.

In the group of four actions in the group "Urban planning", the highly prioritized and medium term predicted is "Urban planning to avoid flood risk". The action presumes avoiding a construction in flooding areas, planning protection for the areas in the risk of flood, and storm water services planning. Apart from this action, as a medium priority, a "Belgrade Climate Atlas" creation is proposed in a short term, up to two years, aiming at presenting the distribution of temperatures and flows of cold air. The "Urban settings" (medium priority, short term) is directed to preserving and improving compactness of urban structure, reducing urban heat islands, and planning reserved infrastructure for public, bicycle and pedestriantransport. The fourth action titled "Urban texture" encourages using appropriate materials for design of landscapes in densely

8 More on the planning the green infrastructure in the context of adaptation to climate changesin Crnčević, 2016. built areas, areas with limited greenery, city centre, and new residential and commercial areas.

There are only two actions in the category "Building design", both low priority and medium term/continual. The actions are "Heat adapted design" and "Flood adapted design". The heat adapted design is proposed in densely build areas, areas with limited greenery, central zones and new residential and mixed use zones. Unlike other measures, in charge for implementation of this measure are building owners with support of the City authorities, as well as Secretariat for Urban Planning and Constructions. The action will include improved insulation, natural ventilation, applying reflective surfaces, design of semi-permeable surfaces on roads and parking pavements, using bright colours, etc. The flood adapted design is planned for the flood prone areas and the implementation is in domain of Secretariat for Urban Planning. This action introduces the guidelines for design in flood-prone areas, avoiding flood damages to buildings.

Under the "Non-structural measures" six actions are proposed. The high priority is given to "Awareness raising and behaviour change" (mediumterm), as well as to "Informing the publicabout adaptation to extreme events" (medium term), "Institutional and organizational measures" (short term) and "Warming system" (short/medium term). In the category of the "Nonstructural measures", the medium priority actions are "Land use and urban planning" (medium term) and "Mapping" (short term). The "Awareness raising and behaviour change" is related to getting a wide audience aware of climate event risks and a necessity to change quotidian habits in transport, using of fuels, saving of water, etc. Although assigned to two City of Belgrade secretariats, Secretariat for Environment and Secretariat for Transport, this action presumes engaging media, organizing conferences and promotions, printing related materials and using all kinds of information distribution. Very similar are next three actions starting from informing a wide public ("Informing the public about adaptation to extreme events"), coordinating activities ("Institutional and organizational measures") and establishing a Climate Watch System("Warning system"). The "Land use and urban planning action"is aimed at reducing the impact of extreme weather events trough urban planning and urban renewal. The "Mapping" is aimed at creating the heat island maps, flood and drought maps and identification of vulnerable groups.

\section{CRITIQUE OF THE PRESENTED ADAPTATION ACTION PLAN}

The legislative framework related to climate changes in Serbia is quite wide ${ }^{9}$, but the country, as well as the biggest cities, still missesa climate change adaptation strategy ${ }^{10}$. The development of theClimate Change Adaptation Action Plan is an important step towards building long-term resilience of the Serbian capital. At the moment many cities and

\footnotetext{
9 Pucar 2013, 0p. Cit. pp. 101.

10 Initial National Communication of the Republic of Serbia... 2010
} 
towns around the world have their adaptation plans strategically shaped by highest authorities, and actions defined and applied (Živković, Đorđević 2016, pp. 80). Two cities in the region, Tirana and Podgorica, have adopted their adaptation action plans as well (Adapting our city..., 2015; Podgorica climate change adaptation. . . 2015).

The presented document gives a detailed exposure and sensitivity analysis for the City of Belgrade through the vulnerability assessment for the recent, current and predicted climate events.It is multi-sectoral, location specific, based mainly on local technical expertise and leads towards the responsive climate policies. It recognizes the most vulnerable groups for each of the climate events. It however does not distinguish the urban poor and the inhabitants of informal or temporary settlements. A community based participatory approach could be useful in the process of understanding specific consequences of climate changes as well as in estimating the adaptive capacities (Dimitrijević, 2013 (c)).

For some parts of the City of Belgrade administrative territory, the recent extreme climate events (the flood in 2014) had disastrous implications. For such parts of the city a disaster risk reduction (DRR) plan should be presented and interlinked with the Adaptation Action Plan.

In developing countries, the financial aspect might be critical when planning climate change adaptation actions ${ }^{11}$. Climate adaptation finance is the aspect missing from the presented Adaptation Plan. Distinguishing low-cost (or no cost), medium and costly actions would be helpful in proposing financial schemes for supporting particular adaptation measures. According to the information of the World Bank, financial resources for adaptation could be local, national and international, both public and private ${ }^{12}$.

Some of the analysed actions (Building design, Heat adapted design) are addressed to building owners with support of City of Belgrade,and to theSecretariat for Urban Planning and Construction. In this case, wider professional circles should be informed and include more practicing architects. The same approach could be applied for "Flood adapted design" for which best practices from other cities could be shared.

In the present Adaptation Action Plan for Belgrade, inclusion of several case studies for different characteristic points of the city would be useful, as it has been done for the City of Tirana ${ }^{13}$. The carefully selected case studies might showcase planned or ongoing projects, in which a set of actions has been applied.

Finally, the Adaptation Action Plan may well be interlinked with scientific technological research projects relevant for climate change and urban development, e.g. Spatial, Environmental, Energy and Social Aspects of Developing Settlements and Climate

11 Guide to Climate Change Adaptation in Cities, World Bank Group, 2011, Chapter Financing Adaptation in Cities, pp. 77 - 86

12 lbid.pp.77

13 Adapting our City..., 0p. cit. pp. $43-70$
Change - Mutual Impacts,funded by the Serbian Ministry of Education and Science, through engaging representative researcher ${ }^{14}$. Such interlinking could be beneficial both for the city and the research institutions. The city will acquire up-to-date knowledge and the research institutions will have opportunity to apply the research results into real-life projects ${ }^{15}$.

\section{CONCLUSION}

The climate change has been recognized as one of the biggest challenges for the contemporary settlements, and the Belgrade City Council used the opportunity to participate in the regional project funded by $\mathrm{GIZ}$, to perform the vulnerability assessment of its entire administrative territory and to develop the climate change adaptation action plan.

The document that appeared in autumn 2015 interlinks the climate adaptation activities with the existing strategic and legislative framework in Serbia. In the vulnerability assessment process it uses methodology developed in the EU project Future Cities. The assessment of current vulnerability in Belgrade is made against extreme weather events: heat waves, extreme cold, droughts, heavy precipitation and floods, and storms. For each weather event the following receptors are analyzed: population, infrastructure, built environment and economy. The spatial distribution of potential impacts has been mapped. The action plan consists of 23 well explained actions divided in five categories: urban green structure, water systems, urban planning, building design, non-structural measures. According to the applied multi-criteria analysis, the green infrastructure development and the flood protection arethe highest priority measures. In the annexes of the Adaptation Action Plan a list of involved participants from all the sectors is given, as well as vulnerability assessment for the past events, assessment of current vulnerability, and assessment of future risks and opportunities due to climate change in Belgrade.

Main purpose of the presented Belgrade Adaptation Action Plan is to raise awareness of local climate change, a necessity to act, if possible, towards mitigation of climate change, and to adapt to unavoidable change. It gives directions divided in five sections of interest toparticular city agencies. Although the actions are to be implemented by Belgrade city agencies, they are equally useful for professionals (planers, architects, educators...), policy makers, interest groups, investors, etc. Apart from its main purpose, the potential influence of the Belgrade Adaptation Action Planis trifold. It will serve as a starting point for developing many other action plans for cities and towns in Serbia. Regionally, it might serve as an example of a good practice together with Podgorica and Tirana, within the GIZ supported project, as well as for the other capital cities in the region. And finally, it is an excellent material to use while creating a national climate change adaptation strategy. For other Serbian cities and towns, the presentedBelgrade Adaptation

14 Pucar, Nenković Riznić, 2016; Devetaković, Pucar, Gajin 2016

15 For example Živković, Đorđević, 2016; Đukić, Antonić, 2016; etc. 
Action Plan is certainly an example and a stimulus to examine specific vulnerability and to create action plans according to local context and capabilities. For the cities of Podgorica and Tirana, the Belgrade Adaptation Action Plan is a good comparative example of a detailed vulnerability assessment of local receptors that have been done for each of the cities. There are certainly some similarities within the adaptation actions that could be shared, regardless of differences in local climate of the cities.

The critique of the presented Adaptation Action Planidentifies a missed economic and financial side in both vulnerability assessment and action plan, i.e. what was the cost for addressing the vulnerability aspects and how particular actions will be financed. Unlike the Adaptation Action Plan for Tirana, the Belgrade document does not give some examples of the proposed actions application in particular parts of the city.

Finally, the appearance of the Adaptation Action Plan in two languages, Serbian and English, makes the document regionally visible andaccessible, contributing to the inclusion of the City of Belgrade in the society of European capitals working seriously on their development, mitigating the climate change as much as possible, and strategically adapting to the unavoidable climate circumstances.

\section{Note:}

This study is created within the technological scientific project TR36035 titled: "Spatial, Environmental, Energy and Social Aspects of Developing Settlements and Climate Change - Mutual Impacts" and project III 47014 titled: "The role and implementation of the national spatial plan and regional development documents in renewal of strategic research, thinking and governance in Serbia", funded by Serbian Ministry of Education, Science and Technological Development.

\section{REFERENCES:}

Action Plan for Adaptation to Climate Change with Vulnerability Assessmen for the City of Belgrade, Balkans Green Energy News, February 2016, http:// balkangreenenergynews.com/action-plan-for-adaptation-to-climate-changewith-vulnerability-assessment-for-the-city-of-belgrade/(accessed May 2017)

Adapting our city to a changeing climate; Vulnerability assesment and adaptation action plan for Tirana (2015), Directorate of Environmental Policies and Environmental Education, Municipality of Tirana, Albania, https://www.giz.de/ de/downloads/Tirana_Adaptation_Plan_EN.pdf(accessed May 2017)

Akcioni plan adaptacijenaklimatskepromenesaprocenomranjivosti (2015), Službeni list GradaBeograda (Official Gazette of the City of Belgrade), No. 65/15, October 26, 2015, http://sllistbeograd.rs/cyr/arhiva/2015/(accessed May 2017)

Climate Change Adaptation Action Plan and Vulnerability Assessment (2015) City of Belgrade, Secretariat for Environmental Protection, Belgrade,http:// klimatskepromenebeograd.rs/wp-content/uploads/2015/11/Climate-ChangeAdaptation-Action-Plan.pdf(accessed May 2017)

Climate Change Adaptation in Western Balkan(2014),Agriwaterpedia, http:// agriwaterpedia.info/images/2/22/Factsheet_Climate_Change_Adaptation_ in_the_Western_Balkan_2012.pdf(accessed May 2017)

Climate change adaptation in the Western Balkans(2014), GIZ,https://www.giz.de/ en/worldwide/29000.html(accessed May 2017)

Crnčević, T. (2016): Green infrastructure planning in the context of adaptation of urban environment to climate change, Prostorni, ekološki, energetski i društveni aspekti razvoja naselja i klimatske promene (Ed. Mila Pucar and Marina NenkovićRiznić), IAUS, Belgrade, pp. 215-232

Devetaković, M., Pucar, M., Gajin, S. (2016): Neki aspekti formiranja baze znanja za podršku tehnološkom projektu TR36035, Klimatske promene, nacionalne politike i lokalni razvoj (ed. Milica Bajić Brković), Arhitektonski fakultet Univerziteta u Beogradu, pp. 91 - 121

Devetaković M., Radojević M. (2014): Greening the blue - An example of institutional contribution to the global culture of climate neutrality,Arhitektura i urbanizam No. 39, pp. 45-61
Dimitrijević, B. (a, 2013): Globalnapromjenaklimeimogućeposljedice(Climate change and the built environment); (limate change and the built environment, Policies and practice in Scotland and Serbia, (Ed. Mila Pucar, BrankaDimitrijević, Igor Marić), IAUS Special Issues No. 70, Belgrade 2013, pp. 20-22

Dimitrijević, B. (b, 2013): Prilagođavanjeklimatskimpromjenama(Adapting to climate change); (limate change and the built environment, Policies and practice in Scotland and Serbia, (Ed. Mila Pucar, BrankaDimitrijević, Igor Marić), IAUS Special Issues No. 70, Belgrade 2013, pp. 23-26

Dimitrijević, B. (c, 2013):Konsultacijesastanovništvom u planiranjuiregeneracijinaselja (Community consultation in planning and regeneration of settlements), Climate change and the built environment, Policies and practice in Scotland and Serbia, (Ed. Mila Pucar, BrankaDimitrijević, Igor Marić), IAUS Special Issues No. 70, Belgrade 2013, pp. 439-445

Djukić, A., Antonić, B. (2016):Smart city concept as a response to climate change, Prostorni, ekološki, energetski i društveni aspekti razvoja naselja i klimatske promene (Ed. Mila Pucar and Marina Nenković-Riznić), IAUS, Belgrade, pp. 15-32 Future Cities Adaptation Compass(2013), Future Cities,

http://www.future-cities.eu/project/adaptation-compass/(accessed May 2017)

World Bank Group (2011): Guide to Climate Change Adaptation in Cities,http://siteresources.worldbank.org/INTURBANDEVELOPMENT/

Resources/336387-1318995974398/GuideClimChangeAdaptCities.pdf(accessed December 2016)

Initial National Communication of the Republic of Serbia under the United Nations Framework Convention on Climate Change(2010),The Ministry of Environment and Spatial Planning of Serbia, http://unfccc.int/resource/docs/natc/srbnc1. pdf(accessed May 2017)

Spatial, Environmental, Energy and Social Aspects of Developing Settlements and Climate Change - Mutual Impacts, 2017,Knowledge Base supporting the project TR36035, http://e-science.amres.ac.rs/TP36035/(accessed May 2017)

Podgorica Climate Change Adaptation, Vulnerability Assessment and Adaptation Action Plan (2015), Secretariat for Spatial Planning and Environmental Protection, Capital City of Podgorica, Montenegro, http://www.sekretarijatza-plurzs.podgorica.me/sites/podgorica.me/files/Urbanizam/Dokumenta/ pg_urban_cca_final_engl_05082015-edited.pdf(accessed May 2017)

Pucar, M. (2013):Energetskiaspektirazvojanaseljaiklimatskepromene -stanje, mogućnosti, strategijeizakonska regulative u Srbiji (Energy aspects of developing settlements and climate change - status, opportunities, strategies and legislation in Serbia), Climate change and the built environment; Policies and practice in Scotland and Serbia (Ed. Mila Pucar, BrankaDimitrijević, Igor Marić), IAUS Special Issues No. 70, Belgrade, pp. 57-108

Pucar, M.; Nenković Riznić, M. ed. (2016):Prostorni, ekološki, energetski i društveni aspekti razvoja naselja i klimatske promene, IAUS, Beograd

Urban adaptation to climate change in Europe; Challenges and opportunities for cities together with supportive national and European policies(2012), European Environmental Agency Report, https://www.eea.europa.eu/publications/ urban-adaptation-to-climate-change(accessed May 2017)

Živković, J.; Đorđević, A. (2016): Role of open spaces in adapting cities to climate change: recommendations for Serbian cities, Prostorni, ekološki, energetski društveni aspekti razvoja naselja i klimatske promene (Ed. Mila Pucar and Marina Nenković-Riznić), IAUS, Belgrade 2016, pp. 65-92 